\title{
Teaching Video NeuroImages: Rippling muscle disease with caveolin myopathy
}

Pierre R. Bourque, MD, Ari Breiner, MD, John Brooks, and Jodi Warman Chardon, MD

Neurology ${ }^{\circledR}$ 2018;91:e1726-e1727. doi:10.1212/WNL.0000000000006427
Correspondence

Dr. Bourque

pbourque@toh.ca

Figure Moderate hypertrophy of the quadriceps, but normal muscle bulk otherwise

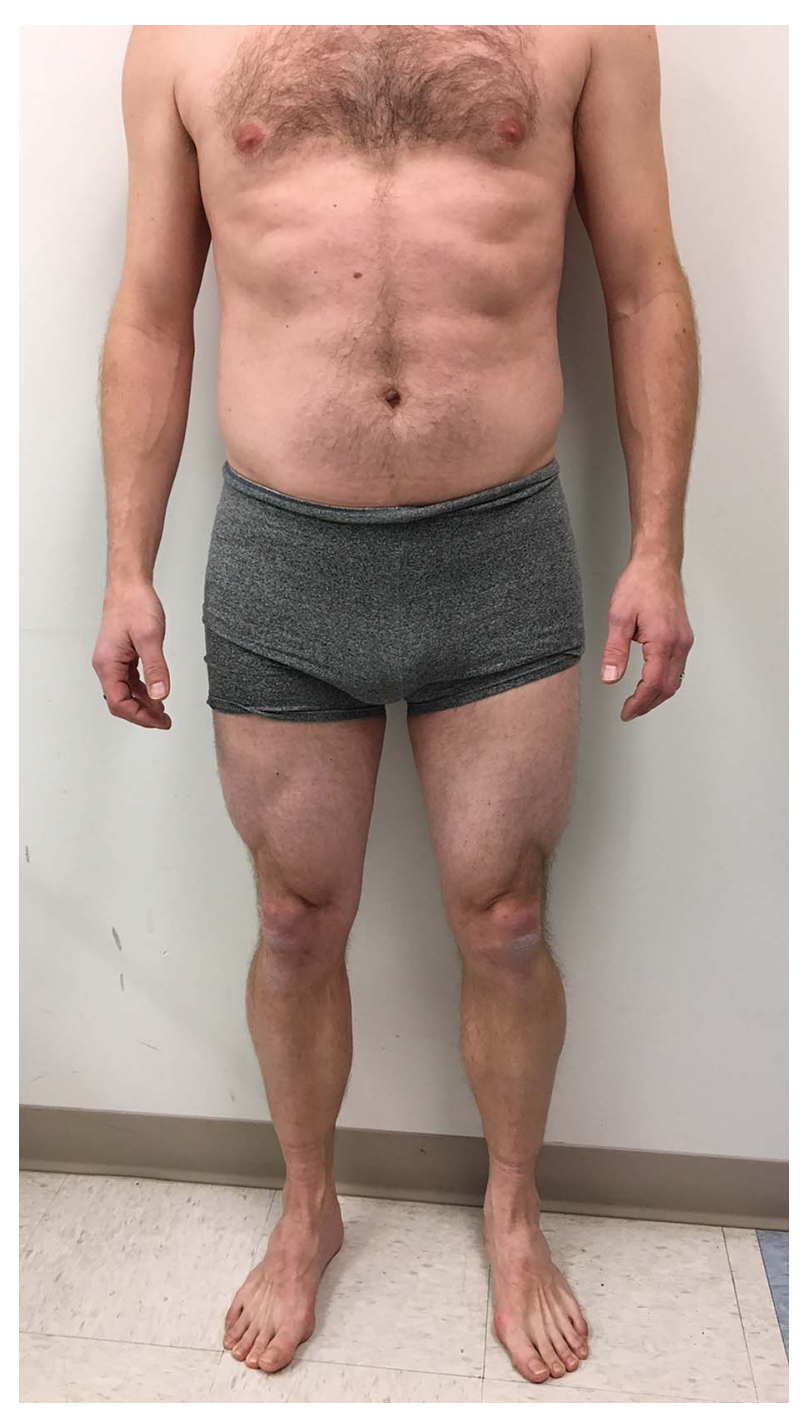

A 43-year-old man described adolescence-onset abnormal muscle contractions. On examination, there was hypertrophy (figure) with normal power of thigh muscles but mild weakness of distal leg muscles (Medical Research Council grade 4+/5). Muscle percussion and stretching induced electrically silent slow rolling muscle contractions (video 1 ). He had mildly elevated creatine kinase $(600 \mathrm{U} / \mathrm{L})$. Family history was consistent with autosomal dominant rippling
MORE ONLINE

- Video

$\rightarrow$ Teaching slides

links.lww.com/WNL/A723

From the Department of Medicine, Division of Neurology (P.R.B., A.B., J.B., J.W.C.), The Ottawa Hospital; The Ottawa Hospital Research Institute (P.R.B., A.B., J.W.C.); and Department of Genetics (P.R.B., A.B., J.W.C.), Children's Hospital of Eastern Ontario, Ottawa, Canada.

Go to Neurology.org/N for full disclosures. Funding information and disclosures deemed relevant by the authors, if any, are provided at the end of the article. 
muscle disease. ${ }^{1} \mathrm{~A}$ heterozygous variant was documented in coding exons of the caveolin 3 gene ( $C A V$ c. $83 \mathrm{~A}>\mathrm{T}$; p.Asp28Val).

In addition to RMD, allelic caveolin disorders include benign hyperCKemia, distal myopathy, limb girdle muscular dystrophy $1 \mathrm{C}$, and isolated hypertrophic cardiomyopathy. ${ }^{2}$

\section{Author contributions}

P.R. Bourque: clinical data acquisition, manuscript preparation. A. Breiner: critical review of manuscript. J. Brooks: video editing, manuscript review. J. Warman Chardon: genetic analysis, critical review of manuscript.

\section{Study funding}

No targeted funding reported.

\section{Disclosure}

The authors report no disclosures relevant to the manuscript. Go to Neurology.org/N for full disclosures.

\section{References}

1. Torbergsen T. Rippling muscle disease: a review. Muscle Nerve 2002; 11:S103-S107.

2. Galbiati F, Minetti C, Lisanti MP. Caveolinopathies: mutations in caveolin-3 cause four distinct autosomal dominant muscle diseases. Neurology 2004;62:538-543. 


\section{Neurology}

Teaching Video NeuroImages: Rippling muscle disease with caveolin myopathy Pierre R. Bourque, Ari Breiner, John Brooks, et al.

Neurology 2018;91;e1726-e1727

DOI 10.1212/WNL.0000000000006427

This information is current as of October 29, 2018

\section{Updated Information \&} Services

References

Subspecialty Collections

Permissions \& Licensing

Reprints including high resolution figures, can be found at: http://n.neurology.org/content/91/18/e1726.full

This article cites 2 articles, 1 of which you can access for free at: http://n.neurology.org/content/91/18/e1726.full\#ref-list-1

This article, along with others on similar topics, appears in the following collection(s):

All Genetics

http://n.neurology.org/cgi/collection/all_genetics Clinical neurology examination

http://n.neurology.org/cgi/collection/clinical_neurology_examination Muscle disease

http://n.neurology.org/cgi/collection/muscle_disease

Information about reproducing this article in parts (figures,tables) or in its entirety can be found online at:

http://www.neurology.org/about/about_the_journal\#permissions

Information about ordering reprints can be found online:

http://n.neurology.org/subscribers/advertise

Neurology ${ }^{\circledR}$ is the official journal of the American Academy of Neurology. Published continuously since 1951, it is now a weekly with 48 issues per year. Copyright () 2018 American Academy of Neurology. All rights reserved. Print ISSN: 0028-3878. Online ISSN: 1526-632X.

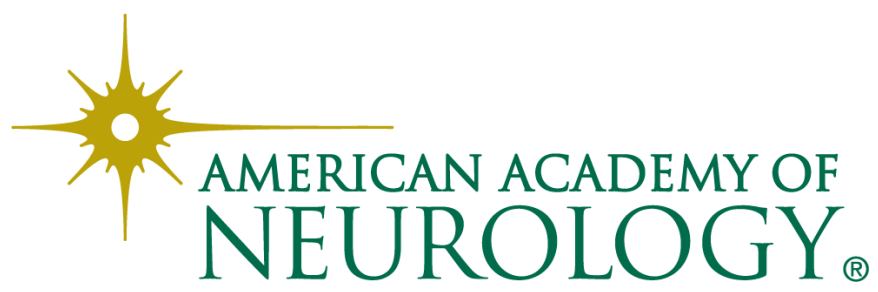

